\title{
The influence of dietary iron and molybdenum on copper metabolism in calves
}

\author{
BY W. R. HUMPHRIES, M. PHILLIPPO, B. W. YOUNG AND I. BREMNER \\ Rowett Research Institute, Bucksburn, Aberdeen AB2 9SB, Scotland
}

(Received 22 March 1982 - Accepted 8 July 1982)

\begin{abstract}
1. Twenty heifer calves were allocated to four groups and maintained for 32 weeks on a diet based mainly on barley and straw and containing $4 \mathrm{mg}$ copper $/ \mathrm{kg}$. The diet was supplemented with 0 or $800 \mathrm{mg}$ iron $/ \mathrm{kg}$ and 0 or $5 \mathrm{mg}$ molybdenum $/ \mathrm{kg}$.

2. Liver and plasma $\mathrm{Cu}$ concentrations, erythrocyte superoxide dismutase $(E C 1,15,1.1)$ and plasma caeruloplasmin ( $E C$ 1.16.3.1) activities decreased greatly and rapidly in all calves given the Fe or Mo supplements or both. Levels indicative of severe $\mathrm{Cu}$ deficiency were attained within 16 weeks. There were no significant differences in values in animals given $\mathrm{Fe}$, Mo or Fe plus Mo.

3. Clinical signs of $\mathrm{Cu}$ deficiency developed after 20 weeks in the calves given the Mo supplement. Growth rates were reduced, skeletal lesions developed and hair texture and colour were affected. No such effects were observed in the calves given only the Fe supplement.

4. Plasma and liver Fe concentrations increased in calves given the Fe supplement but were not greatly affected by Mo, even when the calves were severely $\mathrm{Cu}$-deficient.

5. The significance of the effects of $\mathrm{Fe}$ and $\mathrm{Mo}$ on $\mathrm{Cu}$ metabolism are discussed with special regard to the influence of soil ingestion on $\mathrm{Cu}$ availability and to the frequent lack of correlation between the $\mathrm{Cu}$ status of animals and their clinical condition.
\end{abstract}

The development of copper deficiency in ruminant animals can usually be attributed to the presence of dietary factors which reduce the availability of Cu (see Bremner \& Davies, 1980). Molybdenum and sulphur are probably the most important of these but metals such as zinc and iron can also affect $\mathrm{Cu}$ utilization, at least under experimental conditions. Little is known, however, of the quantitative aspects of the interactions between $\mathrm{Cu}$ and its dietary antagonists and their practical significance is often a matter of conjecture. A further complication is that there is some doubt as to whether the clinical lesions which develop in conditioned $\mathrm{Cu}$ deficiencies are necessarily identical to those found in simple $\mathrm{Cu}$ deficiency.

For Fe, the poor performance of dairy cattle in some areas of New Zealand was attributed to hypocuprosis induced by the high Fe content of water supplies (Coup \& Campbell, 1964; Campbell et al. 1974). This view was supported by the reduced liver $\mathrm{Cu}$ concentrations in cattle and sheep given diets with 1500-3200 mg Fe/kg (Standish et al. 1969, 1971; Campbell et al. 1974; Grun et al. 1978). However, associated increases in $\mathrm{S}$ intake and reductions in food intake may have contributed to some of these results. Perhaps because of this, and the excessive amounts of Fe used, little attention has been paid subsequently to the importance of $\mathrm{Fe}$ in the occurrence of $\mathrm{Cu}$ deficiency under field conditions.

Our interest in the effects of $\mathrm{Fe}$ on $\mathrm{Cu}$ metabolism was stimulated by the findings that silages in North-east Scotland often contain $2000-4000 \mathrm{mg} \mathrm{Fe} / \mathrm{kg}$ dry matter (DM) and that cattle given these silages frequently become hypocupraemic. Even though much of this Fe is derived from soil contamination of the silage, the work of Healy (1972) indicates that a significant proportion of the $\mathrm{Fe}$ would be released within the alimentary tract.

The aim of this investigation was, therefore, to determine the effect of $\mathrm{Fe}$, at a level thought to be similar to that of the 'available' $\mathrm{Fe}$ in silage, on the $\mathrm{Cu}$ status of calves and to compare any clinical lesions which developed with those induced by Mo. A secondary 
aim was to establish whether high dietary Fe synergized the adverse effect of Mo on $\mathrm{Cu}$ utilization by enhancing the excessive hepatic accumulation of $\mathrm{Fe}$ often noted in $\mathrm{Cu}$ deficient animals and precipitating the onset of liver dysfunction and growth failure (Mills, 1980). The results show that $\mathrm{Fe}$ greatly reduced the retention of $\mathrm{Cu}$ but, in contrast to animals given $\mathrm{Mo}$, did not induce clinical signs of $\mathrm{Cu}$ deficiency. There was no major synergistic action of $\mathrm{Mo}$ and $\mathrm{Fe}$ on any aspect of $\mathrm{Cu}$ metabolism.

A preliminary report of the results has been published (Humphries et al. 1981).

\section{EXPERIMENTAL}

\section{Animals and diets}

Sixteen Hereford-Friesian and four Aberdeen Angus heifers, aged approximately 3 weeks, were maintained for 1-3 months on a commercial fat-supplemented milk substitute ration containing $<1 \mathrm{mg} \mathrm{Cu} / \mathrm{kg}$ DM (Volac Ltd, Wendy, Royston, Herts.) to deplete their liver $\mathrm{Cu}$ reserves. The calves were then weaned onto a ration based on ground barley and barley straw (Table 1) containing $4 \mathrm{mg} \mathrm{Cu}, 0.1 \mathrm{mg} \mathrm{Mo}, 100 \mathrm{mg} \mathrm{Fe}$ and $2.8 \mathrm{~g} \mathrm{~S} / \mathrm{kg}$ DM. This diet was offered for 3 months, until liver $\mathrm{Cu}$ concentrations were reduced to approximately $100 \mathrm{mg} / \mathrm{kg}$ DM. Calves were then allocated in a randomized block design on the basis of breed and liver $\mathrm{Cu}$ to four treatment groups (Con, Fe, Mo and FeMo). These were given ad lib. the diet described in Table 1 but with the addition of saccharated ferrous carbonate or ammonium molybdate (BDH Chemicals, Poole, Dorset) or both to provide an additional 0 or $800 \mathrm{mg} \mathrm{Fe} / \mathrm{kg}$ and 0 or $5 \mathrm{mg} \mathrm{Mo} / \mathrm{kg}$. The animals were kept in individual pens in a 'trace-element-free' environment and were given deionized water to drink. The experiment was terminated after 32 weeks. Animals were weighed and food intakes recorded weekly. Blood and liver biopsy samples were collected at 2- and 4-week intervals respectively.

\section{Analytical methods}

$\mathrm{Cu}$ and $\mathrm{Zn}$ concentrations were measured by atomic absorption spectroscopy after digestion of solid samples with nitric acid:perchloric acid:sulphuric acid $(4: 1: 0 \cdot 5$, by vol.) or after precipitation of blood or plasma proteins with 3 vols trichloroacetic acid $(100 \mathrm{~g} / 1)$. Plasma $\mathrm{Fe}$ and unsaturated Fe-binding capacity were measured with ferrozine as described by Ruutu (1975). Tissue Fe was measured by the method of Kennedy (1927). Mo in plasma and in diets was determined by the methods of Quin \& Woods (1979) and Bingley (1959) respectively. Dietary $S$ was measured using $X$-ray fluorescence spectrometry.

Plasma caeruloplasmin ( $E C 1$ 16.3 1) activities were measured by the method of Smith $\&$ Wright (1974). Superoxide dismutase (SOD) (EC 1.15 .1 .1) activities were determined by the method of Beauchamp \& Fridovich (1971), using bovine erythrocyte SOD as standard (Miles Laboratories, Slough).

Statistical analysis of results was carried out by analysis of variance, unless otherwise stated.

\section{RESULTS}

Growth and clinical condition of calves

None of the dietary treatments affected the growth of the calves until weeks 20-24, when significant reductions $(\mathrm{P}<0.05)$ in the weight of both groups of Mo-treated calves (Mo and FeMo) became evident (Table 2, Fig. 1). This inhibitory effect of Mo on growth was even more pronounced during the last 8 weeks of the experiment, when the weight gain of the Mo-treated calves was only $72 \%$ of that in the calves in groups Con and Fe. Dietary supplementation with Fe did not influence growth at either level of Mo intake.

The inhibitory effect of Mo on growth during weeks 24-32 could be partly attributed to reductions in food intake, since this was only $87 \%$ of that in the calves given no Mo 
Table 1. Composition of diet $\dagger(\mathrm{g} / \mathrm{kg})$

\begin{tabular}{lclc}
\hline \hline Ground barley & $678 \cdot 4$ & $\mathrm{KHCO}_{3}$ & $10 \cdot 24$ \\
Ground barley straw & 200 & $\mathrm{CaHPO}_{4} \cdot 2 \mathrm{H}_{2} \mathrm{O}$ & $9 \cdot 7$ \\
White fish-meal & 50 & $\mathrm{Na}_{2} \mathrm{SO}_{4}$ & $5 \cdot 83$ \\
Molasses & 20 & $\mathrm{CaCO}_{3}$ & $4 \cdot 25$ \\
Urea & 10 & $\mathrm{NaCl}$ & 0.99 \\
Arachis oil & 10 & $\mathrm{MgSO}_{4} \cdot 7 \mathrm{H}_{2} \mathrm{O}$ & $0 \cdot 51$ \\
\hline
\end{tabular}

* The diet was also supplemented with: $\mathrm{CoSO}_{4}$ and $\mathrm{KI}$ to provide $0.1 \mathrm{mg}$ cobalt and $0.8 \mathrm{mg}$ iodine $/ \mathrm{kg}$ diet, retinol $(1.5 \mathrm{mg} / \mathrm{kg})$, cholecalciferol $(25 \mu \mathrm{g} / \mathrm{kg})$ and $\alpha$-tocopherol $(20 \mathrm{mg} / \mathrm{kg})$.

Table 2. Effect of iron and molybdenum on growth, food intake and bone conformation of calves

\begin{tabular}{|c|c|c|c|c|c|c|c|c|}
\hline \multirow{2}{*}{$\begin{array}{l}\text { Treatment group ... } \\
\text { Mo supplement }(\mathrm{mg} / \mathrm{kg}) \\
\text { Fe supplement }(\mathrm{mg} / \mathrm{kg})\end{array}$} & \multirow{2}{*}{$\begin{array}{c}\text { Con } \\
0 \\
0\end{array}$} & \multirow{2}{*}{$\begin{array}{c}\mathrm{Fe} \\
0 \\
800\end{array}$} & \multirow{2}{*}{$\begin{array}{c}\text { Mo } \\
5 \\
0\end{array}$} & \multirow{2}{*}{$\begin{array}{l}\text { FeMo } \\
5 \\
800\end{array}$} & \multirow{2}{*}{$\begin{array}{c}\mathrm{SE} \text { of } \\
\text { difference } \\
\text { between means }\end{array}$} & \multicolumn{3}{|c|}{$\begin{array}{l}\text { Significance of } \\
\text { treatment effects }\end{array}$} \\
\hline & & & & & & $\mathrm{Fe}$ & Mo & $\mathrm{Fe} \times \mathrm{Mo}$ \\
\hline \multicolumn{9}{|l|}{ Wt. $(\mathrm{kg})$ at week } \\
\hline 0 & 144 & 142 & 130 & 125 & 10 & NS & NS & NS \\
\hline 24 & 266 & 289 & 252 & 259 & 20 & NS & * & NS \\
\hline 32 & 342 & 376 & 316 & 310 & 23 & NS & * & NS \\
\hline $\begin{array}{l}\text { Wt. gain }(\mathrm{kg} / \mathrm{d}) \text { during } \\
\text { weeks } 24-32\end{array}$ & 0.84 & 0.97 & 0.70 & 0.61 & 0.09 & NS & $* *$ & NS \\
\hline $\begin{array}{l}\text { Food intake }(\mathrm{kg} / \mathrm{d}) \\
\text { during weeks } 24-32\end{array}$ & $7 \cdot 1$ & 7.8 & $7 \cdot 0$ & $6 \cdot 0$ & 0.5 & NS & ${ }^{*}$ & * \\
\hline $\begin{array}{l}\text { Food conversion ratio } \\
\text { during weeks } 24-32(\mathrm{~kg} \\
\text { intake } / \mathrm{kg} \text { wt gain) }\end{array}$ & 8.9 & $8 \cdot 1$ & $10 \cdot 0$ & $10 \cdot 5$ & $1 \cdot 0$ & NS & * & NS \\
\hline End-width $(\mathrm{mm})$ of metacarpal $\dagger$ & $72 \cdot 4$ & $74 \cdot 8$ & 78.4 & 77.6 & 1.83 & NS & * & \\
\hline End-width $(\mathrm{mm})$ of metatarsal $\dagger$ & $71 \cdot 4$ & $74 \cdot 8$ & $75 \cdot 0$ & $76 \cdot 1$ & 1.42 & * & * & \\
\hline
\end{tabular}

NS, not significant.

${ }^{*} P<0.05,{ }^{* *} P<0.01$.

$\dagger$ End-widths adjusted to shaft widths of 47 and $42 \mathrm{~mm}$ for metacarpals and metatarsals respectively, assuming that there is an increase of $1.4 \mathrm{~mm}$ in end-width per unit increase in shaft width.

(Table 2). However food conversion efficiencies were also affected by Mo, as the calves in groups Mo and FeMo consumed $10.3 \mathrm{~kg}$ food $/ \mathrm{kg}$ live-weight gain during weeks 24-32 compared with $8.5 \mathrm{~kg}$ in the other groups (Table 2). Dietary supplementation with $\mathrm{Fe}$ had no effect on food conversion efficiency although it did slightly reduce food intakes during weeks $24-32$ by the calves given the Mo-containing diets.

The clinical appearance of the calves was also adversely influenced by Mo, whereas treatment with Fe had only minor effects. Calves in groups Mo and FeMo showed loss of hair pigment and changes in hair texture after approximately 20 weeks. Skeletal changes also became evident in these calves at this time. An index of these changes was obtained in the Hereford-Friesian calves by measurement of the end and shaft widths of the metacarpals and metatarsals after 32 weeks. There were significant increases in end widths in both bones in the Mo-treated calves $(P<0.05)$ but only in the metacarpals in the Fe-treated calves (Table 2). The Mo-treated animals also developed the 'stilted gait' characteristic of $\mathrm{Cu}$ deficiency and had difficulty in walking. These symptoms resembled those described by Mills et al. (1976) and Smith et al. (1975).

None of the calves developed diarrhoea during the experiment. 


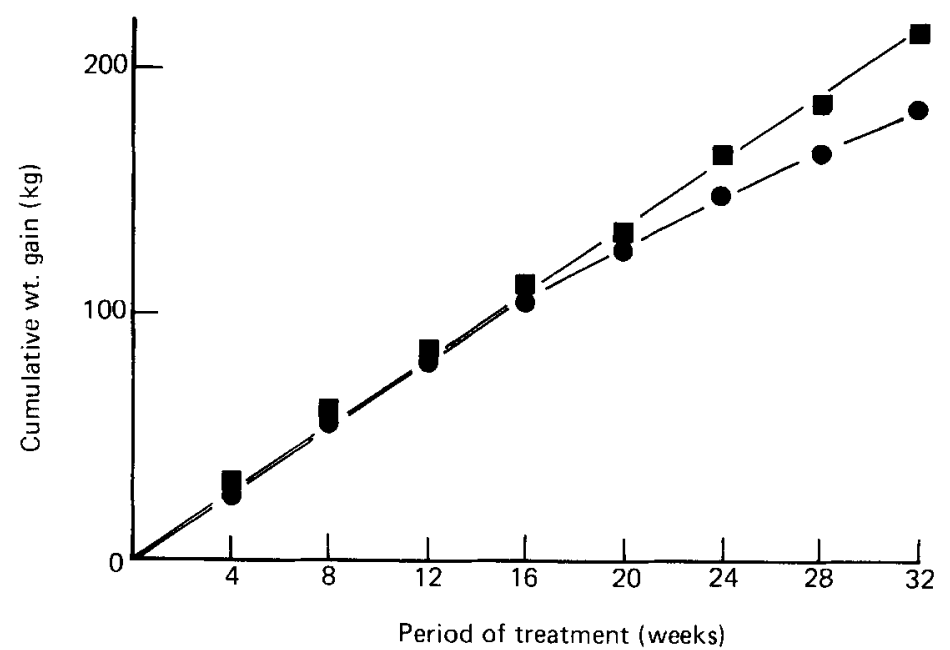

Fig. 1. Cumulative weight gain in calves given diets with no molybdenum (groups Con and $\mathrm{Fe}, \mathbf{D}$ ) or with molybdenum (groups Mo and FeMo,

Table 3. Effect of iron and molybdenum on liver copper and superoxide dismutase (EC 1.15.1.1, SOD) activities in calves

\begin{tabular}{|c|c|c|c|c|c|c|c|c|c|}
\hline \multirow{2}{*}{$\begin{array}{l}\text { Treatment group } \\
\text { Mo supplement } \\
\text { (mg/kg) ... } \\
\text { Fe supplement } \\
\text { (mg/kg) ... }\end{array}$} & \multirow{2}{*}{$\begin{array}{l}\text { Week of } \\
\text { treatment }\end{array}$} & \multirow{2}{*}{$\begin{array}{l}\text { Con } \\
0 \\
0\end{array}$} & \multirow{2}{*}{$\begin{array}{c}\mathrm{Fe} \\
0 \\
800\end{array}$} & \multirow{2}{*}{$\begin{array}{c}\text { Mo } \\
5 \\
0\end{array}$} & \multirow{2}{*}{$\begin{array}{c}\text { FeMo } \\
5 \\
800\end{array}$} & \multirow{2}{*}{$\begin{array}{c}\text { SE of } \\
\text { difference } \\
\text { between } \\
\text { means }\end{array}$} & \multicolumn{3}{|c|}{$\begin{array}{l}\text { Significance of } \\
\text { treatment effects }\end{array}$} \\
\hline & & & & & & & $\mathrm{Fe}$ & Mo & $\mathrm{Fe} \times \mathrm{Mo}$ \\
\hline Liver $\mathrm{Cu}(\mathrm{mg} / \mathrm{kg} \mathrm{DM}) \dagger$ & $\begin{array}{r}0 \\
8 \\
16 \\
24 \\
32\end{array}$ & $\begin{array}{r}110 \cdot 0 \\
72 \cdot 2 \\
61 \cdot 9 \\
49 \cdot 7 \\
72 \cdot 0\end{array}$ & $\begin{array}{r}94 \cdot 5 \\
19 \cdot 2 \\
6 \cdot 5 \\
3 \cdot 9 \\
3 \cdot 6\end{array}$ & $\begin{array}{r}104 \cdot 8 \\
28 \cdot 3 \\
3 \cdot 9 \\
2 \cdot 3 \\
2 \cdot 4\end{array}$ & $\begin{array}{r}104 \cdot 4 \\
19 \cdot 4 \\
5 \cdot 8 \\
3 \cdot 2 \\
2 \cdot 3\end{array}$ & & & & \\
\hline In Liver $\mathrm{Cu}(\mathrm{mg} / \mathrm{kg} \mathrm{DM})$ & $\begin{array}{r}0 \\
8 \\
32\end{array}$ & $\begin{array}{l}4 \cdot 703 \\
4 \cdot 280 \\
4 \cdot 277\end{array}$ & $\begin{array}{l}4 \cdot 549 \\
2 \cdot 956 \\
1 \cdot 284\end{array}$ & $\begin{array}{l}4 \cdot 652 \\
3 \cdot 342 \\
0 \cdot 859\end{array}$ & $\begin{array}{l}4.648 \\
2 \cdot 964 \\
0 \cdot 818\end{array}$ & $\begin{array}{l}0 \cdot 128 \\
0 \cdot 242 \\
0 \cdot 378\end{array}$ & *** & $\stackrel{*}{* * *}$ & $* * *$ \\
\hline $\begin{array}{l}\text { Liver SOD } \$(\mu \mathrm{g} / \mathrm{mg} \\
\text { protein) }\end{array}$ & $\begin{array}{l}16 \\
24 \\
32\end{array}$ & $\begin{array}{c}8 \cdot 26 \\
2 \cdot 70 \\
3 \cdot 76\end{array}$ & $\begin{array}{l}2.69 \\
1.74 \\
1.29\end{array}$ & $\begin{array}{l}3.84 \\
0.96 \\
1 \cdot 16\end{array}$ & $\begin{array}{l}5 \cdot 97 \\
2 \cdot 71 \\
1 \cdot 02\end{array}$ & $\begin{array}{l}1.77 \\
0.61 \\
0.32\end{array}$ & $\begin{array}{l}\text { NS } \\
\text { NS } \\
* * *\end{array}$ & $\begin{array}{l}\text { NS } \\
\text { NS } \\
* * *\end{array}$ & $\begin{array}{c}* \\
* * \\
* * *\end{array}$ \\
\hline
\end{tabular}

DM, dry matter.

NS, not significant.

* $P<0.05, * * P<0.01$, *** $P<0.001$.

+ Calculated as antilogarithm of mean In values.

$\ddagger$ Measured on liver cytosol, obtained after centrifugation of liver homogenates in water at $100000 \mathrm{~g}$ for $1 \mathrm{~h}$

\section{Cu status of calves}

Dietary supplementation with $\mathrm{Fe}$ or Mo or both caused major changes in the $\mathrm{Cu}$ status of the animals, as assessed by tissue or blood $\mathrm{Cu}$ concentrations and by the activities of $\mathrm{Cu}$-dependent enzymes (Tables 3 and 4). Thus liver $\mathrm{Cu}$ concentrations rapidly decreased in all calves in groups Fe, Mo and FeMo (Fig. 2, Table 3). After 8 weeks, concentrations in these groups were less than $30 \mathrm{mg} / \mathrm{kg} \mathrm{DM}$, a threshold level frequently used to diagnose 
Table 4. Effect of iron and molybdenum on copper concentrations and on caeruloplasmin (EC1.16.3.1) and superoxide dismutase (EC1.15.1.1, SOD) activities in blood

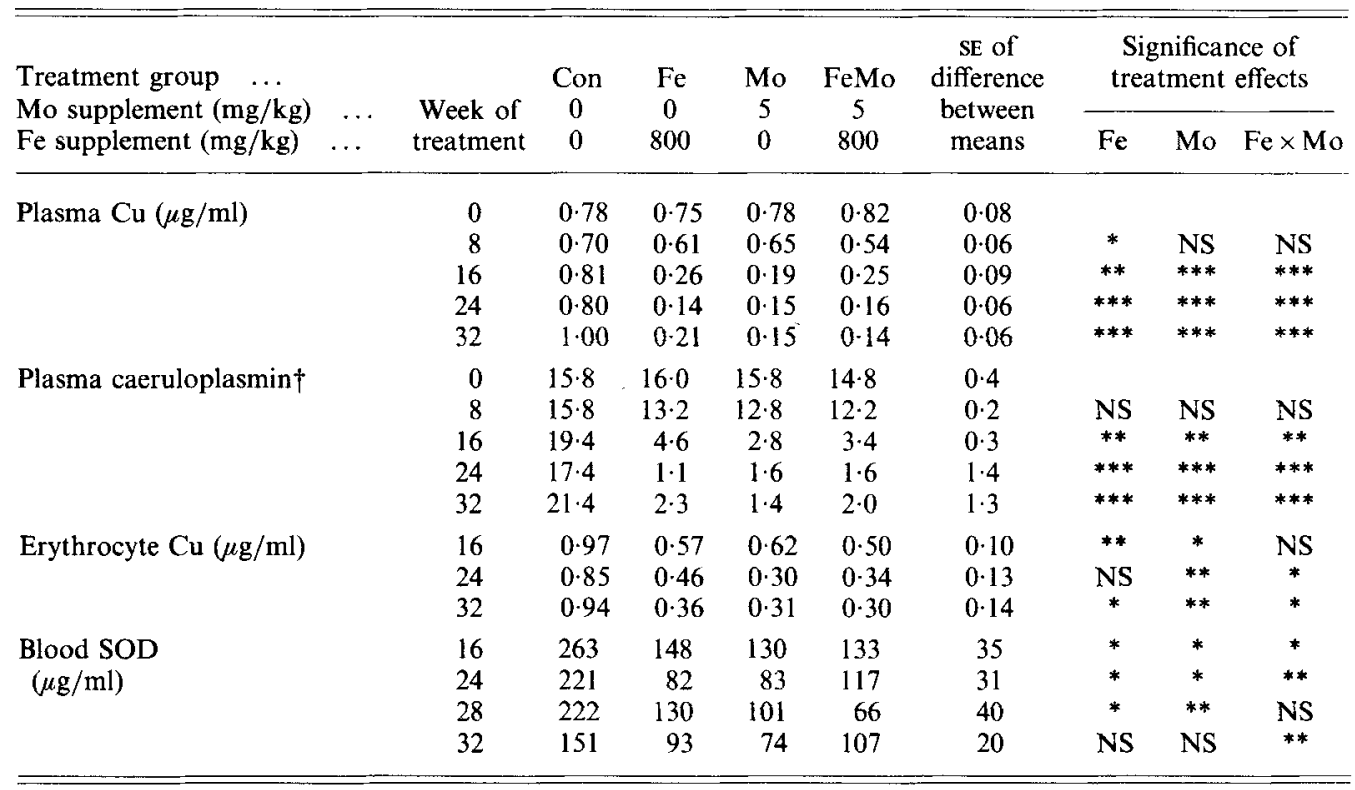

NS, not significant.

${ }^{*} P<0.05$, ** $P<0.01$, *** $P<0.001$.

$f$ Activities are given as change in absorbance $\times 10^{3}$ at $525 \mathrm{~nm} / 0.5 \mathrm{ml}$ plasma per min.

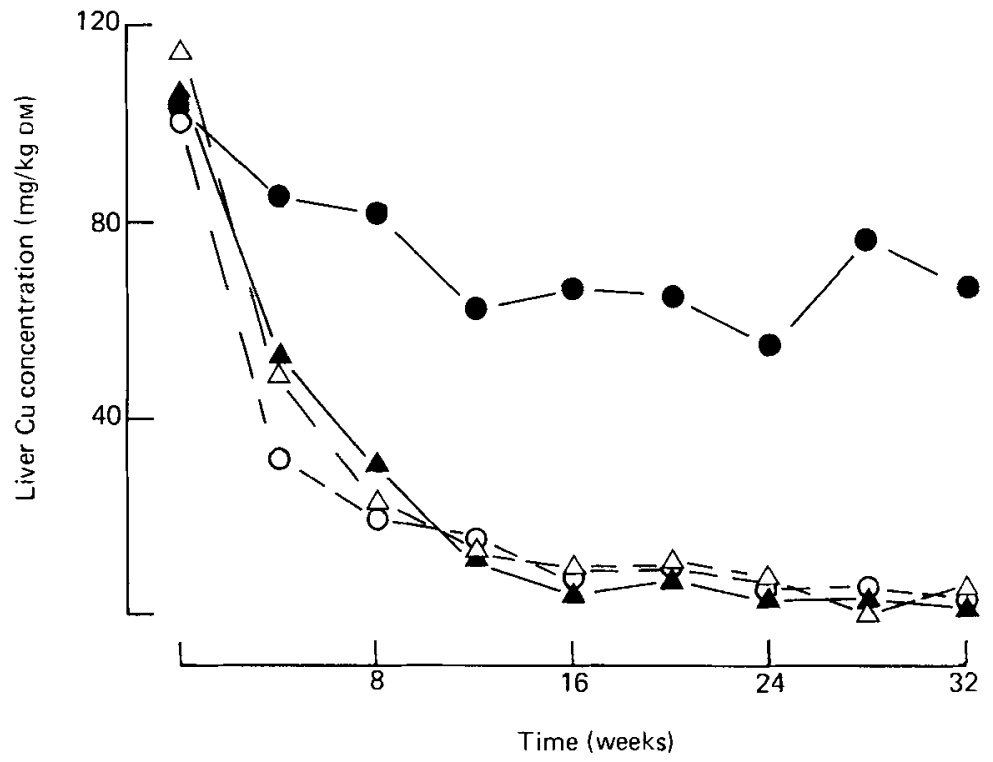

Fig. 2. Effects of dietary supplementation with iron $(O)$, molybdenum $(\boldsymbol{\Delta})$ or Fe and Mo $(\triangle)$ on liver copper concentrations $(\mathrm{mg} / \mathrm{kg}$ dry matter (DM)) in calves. (O), Concentrations in the control calves. 
$\mathrm{Cu}$ deficiency (Roberts, 1976). At 24 weeks, by which time Mo had reduced the rate of growth, liver $\mathrm{Cu}$ had declined to as little as $3 \mathrm{mg} / \mathrm{kg}$ DM. However, liver $\mathrm{Cu}$ fell to equally low concentrations in group $\mathrm{Fe}$, in which growth was unaffected. Significant $\mathrm{Fe} \times \mathrm{Mo}$ interactions occurred throughout the experiment but there were no indications that $\mathrm{Fe}$ and Mo exerted additive effects on the rate of liver $\mathrm{Cu}$ depletion.

The activity of liver cytosolic $(\mathrm{Cu}, \mathrm{Zn})-\mathrm{SOD}$ was reduced in all calves given the $\mathrm{Fe}$ - and Mo-containing diets but there were no consistent differences between groups $\mathrm{Fe}$, Mo and FeMo (Table 3). Significant decreases in enzyme activities took longer to develop and when expressed as a proportion of initial values were much less than the decreases in total liver $\mathrm{Cu}$ content.

Plasma $\mathrm{Cu}$ concentrations in the calves in groups $\mathrm{Fe}$, Mo and FeMo were reduced to only $50 \%$ of the values in the unsupplemented calves (group Con) after 12 weeks and minimum concentrations of $0 \cdot 15-0.20 \mathrm{mg} / 1$ were attained after 20 weeks (Table 4). There were, however, no significant differences in plasma $\mathrm{Cu}$ between the three supplemented groups. Caeruloplasmin activities decreased similarly and were virtually undetectable in all Mo- and Fe-treated calves after 20 weeks (Table 4).

Erythrocyte $\mathrm{SOD}$ and $\mathrm{Cu}$ concentrations decreased by approximately $50 \%$ in the calves in groups $\mathrm{Fe}$, Mo and FeMo at 16 weeks, when these assays were first carried out, and further decreases occurred in the 16-32 week period (Table 4). There were no significant differences between the three groups of supplemented calves.

\section{Iron status of calves}

Dietary supplementation with Fe caused significant but variable increases in plasma and liver Fe concentrations $(P<0.001)$ (Figs. 3 and 4$)$. The greatest plasma Fe concentrations occurred in groups $\mathrm{Fe}$ and FeMo during weeks 4-12, when concentrations were approximately $3.5 \mathrm{mg} / 1$, compared with approximately $2 \mathrm{mg} / 1$ in the calves given no Fe supplements. There were also transient but slight effects of dietary Mo on plasma Fe concentrations which were significantly decreased in both groups of Mo-treated calves during weeks 24-28 $(P<0.05)$.

Total iron-binding capacity (TIBC) of the plasma was inversely related to Fe intake and values in groups $\mathrm{Fe}$ and FeMo were less than those in the other groups from week 20 onwards $(P<0.01)$. Concentrations at week 20 in groups $\mathrm{Con}, \mathrm{Fe}, \mathrm{Mo}$ and $\mathrm{FeMo}$ were $5.62,4.94,6.06$ and $4.98 \mathrm{mg} \mathrm{Fe} / 1$ respectively (SE of difference between means 0.39 ).

The degree of saturation of plasma transferrin was greatly increased by $\mathrm{Fe}$ supplementation during weeks 4-12, when values in groups Fe and FeMo were approximately $80 \%$ and approximately double those in the other groups $(P<0.01)$ (Table 5). Slight effects of Mo on transferrin saturation also occurred during weeks $24-48(P<0.05)$, average values in groups Mo and FeMo being only 34\% compared with $45 \%$ in groups Con and $\mathrm{Fe}$ (Table 5).

Liver Fe concentrations in both groups of Fe-supplemented calves were two to three times greater than those in the other calves at 8 weeks (Fig. 4). Concentrations declined for a short period thereafter but then increased steadily to aproximately $600 \mathrm{mg} / \mathrm{kg} \mathrm{DM}$ from week 20 onwards. Liver Fe concentrations in the calves in groups Con and Mo varied during the experiment but never increased above $300 \mathrm{mg} / \mathrm{kg} \mathrm{DM}$, even in the calves in group Mo showing signs of $\mathrm{Cu}$ deficiency.

The haematological status of the calves was not affected by any treatment. Blood haemoglobin concentrations and packed cell volumes at 32 weeks are given in Table 5 . 


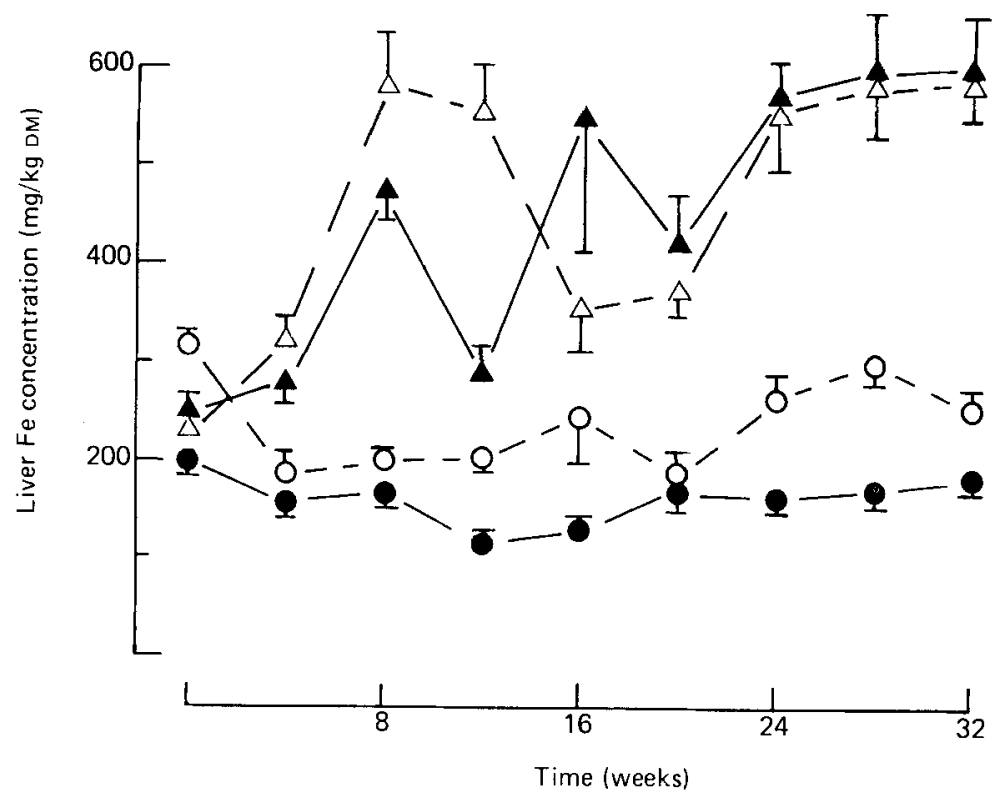

Fig. 3. Effects of dietary supplementation with iron $(\Delta)$, molybdenum $(O)$ or Fe and Mo $(\triangle)$ on liver Fe concentrations $(\mathrm{mg} / \mathrm{kg}$ dry matter $(\mathrm{DM})$ ) in calves. (O), Concentrations in the control calves. The SEMS are indicated by the vertical bars.

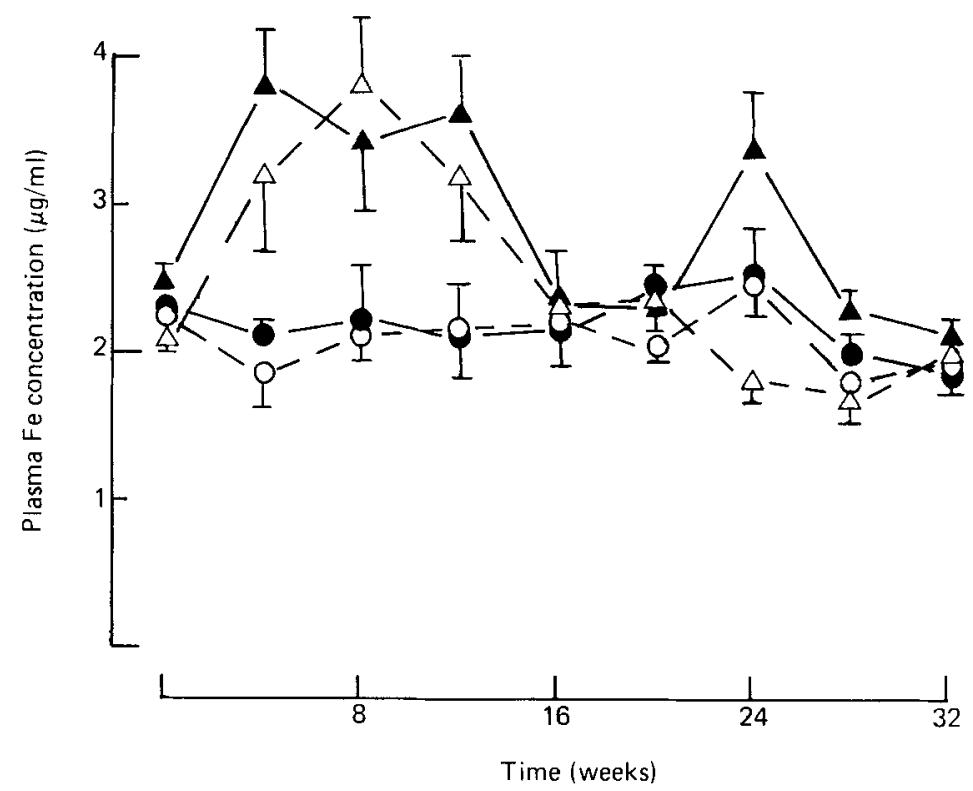

Fig. 4. Effects of dietary supplementation with iron (A), molybdenum (O) or Fe and Mo ( $\triangle$ ) on plasma Fe concentrations $(\mu \mathrm{g} / \mathrm{ml})$ in calves. $(\Theta)$, Concentrations in the control calves. The SEMs are indicated by the vertical bars. 
Table 5. Effects of iron and molybdenum on Fe status of calves

\begin{tabular}{|c|c|c|c|c|c|c|c|c|c|}
\hline \multirow{2}{*}{$\begin{array}{l}\text { Treatment group } \ldots \\
\text { Mo supplement }(\mathrm{mg} / \mathrm{kg}) \\
\text { Fe supplement }(\mathrm{mg} / \mathrm{kg})\end{array}$} & \multirow[t]{2}{*}{$\begin{array}{l}\text { Week of } \\
\text { treatment }\end{array}$} & \multirow{2}{*}{$\begin{array}{c}\text { Con } \\
0 \\
0\end{array}$} & \multirow{2}{*}{$\begin{array}{c}\mathrm{Fe} \\
0 \\
800\end{array}$} & \multirow{2}{*}{$\begin{array}{l}\text { Mo } \\
5 \\
0\end{array}$} & \multirow{2}{*}{$\begin{array}{c}\text { FeMo } \\
5 \\
800\end{array}$} & \multirow{2}{*}{$\begin{array}{l}\text { SE of } \\
\text { difference } \\
\text { between } \\
\text { means }\end{array}$} & \multicolumn{3}{|c|}{$\begin{array}{l}\text { Significance of } \\
\text { treatment effects }\end{array}$} \\
\hline & & & & & & & $\mathrm{Fe}$ & Mo & $\mathrm{Fe} \times \mathrm{Mo}$ \\
\hline $\begin{array}{l}\text { Blood haemoglobin } \\
\text { concentration }(\mathrm{g} / \mathrm{l})\end{array}$ & 32 & 156 & 131 & 140 & 133 & 11 & & & \\
\hline Packed cell volume & 32 & $0 \cdot 408$ & 0.364 & 0.372 & $0 \cdot 370$ & 0.022 & & & \\
\hline Saturation of plasma & 8 & $0 \cdot 383$ & 0.619 & 0.408 & 0.783 & $0 \cdot 086$ & $* * *$ & NS & NS \\
\hline transferrin & 24 & 0.424 & 0.490 & 0.357 & $0 \cdot 331$ & $0 \cdot 038$ & NS & ** & NS \\
\hline
\end{tabular}

\section{$M o$ and $P$}

Plasma Mo concentrations in calves in groups Con and Fe were only $0.01-0.02 \mathrm{mg} / 1$, which was close to the limit of detection for the analytical technique used. As expected, concentrations were greater in the calves given the Mo supplement, and were approximately $0 \cdot 1-0 \cdot 2 \mathrm{mg} / \mathrm{l}$ throughout the 32-week experimental period. Dietary supplementation with Fe also increased plasma Mo concentrations during weeks 4-12 in the calves given Mo $(P<0.01)$. For example, the mean $( \pm$ SEM) concentrations in groups Mo and FeMo at week 8 were $0.081 \pm 0.011$ and $0 \cdot 182 \pm 0.017 \mathrm{mg} / 1$ respectively.

There were no significant effects of Fe or Mo supplementation on P metabolism. Plasma $P$ concentrations after 20 weeks were $92 \cdot 1,89 \cdot 5,96 \cdot 2$ and $91 \cdot 7 \mathrm{mg} / 1$ (sE of difference between means 3.7 ) in groups Con, $\mathrm{Fe}$, Mo and FeMo respectively.

\section{DISCUSSION}

These results clearly indicate that increased dietary Fe intakes can have a marked inhibitory effect on the utilization of dietary $\mathrm{Cu}$ and are in good agreement with the findings of Standish et al. (1969) and of Campbell et al. (1974). It is significant that the addition of only $800 \mathrm{mg} \mathrm{Fe} / \mathrm{kg}$ diet was sufficient to affect the $\mathrm{Cu}$ status of the calves, since this $\mathrm{Fe}$ concentration is within the range found in a variety of animal feedstuffs (Agricultural Research Council, 1976). Indeed, recent findings indicate that a dietary supplement of only $250 \mathrm{mg} \mathrm{Fe} / \mathrm{kg}$ diet is sufficient to reduce hepatic $\mathrm{Cu}$ reserves of calves (I. Bremner, $\mathrm{M}$. Phillippo, W. R. Humphries \& B. W. Young, unpublished results). The effects of Fe on the utilization of $\mathrm{Cu}$ by cattle may, therefore, be of much greater practical importance than has hitherto been recognized.

It is possible, for example, that the inhibitory effect of soil ingestion on $\mathrm{Cu}$ availability to ruminants (Suttle et al. 1975) could be at least partly attributable to an increase in their Fe intake. Concentrations of Fe in soils are frequently approximately $20000 \mathrm{mg} / \mathrm{kg}$ and a significant proportion of the Fe can be liberated on incubation of soil with rumen contents (Healy, 1972). If soil ingestion.accounted for $10 \%$ of an animal's DM intake, during grazing or on silage feeding, and if only $25 \%$ of this Fe were released in the alimentary tract, the level of 'available' Fe would be equivalent to $500 \mathrm{mg} / \mathrm{kg}$, which would be sufficient to affect considerably the utilization of dietary $\mathrm{Cu}$.

The addition of $800 \mathrm{mg} \mathrm{Fe} / \mathrm{kg}$ diet had the same effect on all indices of $\mathrm{Cu}$ status of the calves as did $5 \mathrm{mg} \mathrm{Mo} / \mathrm{kg}$, a concentration of Mo which has previously been shown to decrease the utilization of $\mathrm{Cu}$ by cattle and sheep (Suttle, 1975; Mills et al. 1977) and to induce $\mathrm{Cu}$ deficiency under practical conditions (Smith et al. 1975). Thus liver, plasma and 
erythrocyte $\mathrm{Cu}$ content and erythrocyte SOD activity were identical in the calves given $\mathrm{Fe}$, $\mathrm{Mo}$ or $\mathrm{Fe}$ plus Mo. However, there were important differences in the clinical condition of the calves, since only those given Mo in the diet showed characteristic signs of $\mathrm{Cu}$ deficiency (Mills et al. 1976) such as impaired growth, reduced food conversion efficiency, skeletal abnormalities and changes in hair texture. The subsequent reproductive performance of the heifers was also adversely affected by Mo but not by $\mathrm{Fe}$, since conception rates in groups Mo and FeMo were greatly reduced when the animals were inseminated at the end of the 32-week experimental period (Phillippo et al. 1982).

The absence of these lesions in the Fe-treated animals highlights the inadequacy of current procedures to diagnose clinical $\mathrm{Cu}$ deficiency. Even the assay of erythrocyte SOD content to detect the onset of growth inhibition, as proposed by McMurray (1980), has limitations, since the decreases in the levels of this enzyme were the same in the calves given $\mathrm{Fe}$ or Mo. Assay of this enzyme does not appear to offer any advantage over the measurement of erythrocyte $\mathrm{Cu}$ concentrations. The absence of any increase in liver $\mathrm{Fe}$ content in the Mo-treated calves also indicates that there is no relationship between growth failure in $\mathrm{Cu}$-deficient animals and excessive accumulation of $\mathrm{Fe}$ in the liver (Mills, 1980).

The reason why Mo and $\mathrm{Fe}$ exert such different clinical effects on calves which are ostensibly of the same $\mathrm{Cu}$ status is not known. It may be that Mo induces a more severe $\mathrm{Cu}$ deficiency, which cannot be recognized by conventional measurements of blood or liver $\mathrm{Cu}$ concentrations. Alternatively, Mo may disturb $\mathrm{Cu}$ metabolism at specific sites in the body, where $\mathrm{Fe}$ is without effect. It is well-established that systemic $\mathrm{Cu}$ metabolism is affected in ruminants given relatively large amounts of Mo in their diet (Smith \& Wright, 1974; Bremner \& Young, 1978) and in rats given thiomolybdates and oxythiomolybdates (Mills, El-Gallad \& Bremner, 1981; Mills, El-Gallad, Bremner et al. 1981; Bremner, Mills et al. 1982). Another possibility is that Mo can exert direct effects on certain metabolic processes, independently of any disturbance in $\mathrm{Cu}$ metabolism. The amelioration of this form of molybdenosis by $\mathrm{Cu}$ supplementation could be atrributed to inhibition of $\mathrm{Mo}$ absorption or to restriction in the access of active forms of Mo to sensitive sites (Mason et al. 1978; Mills, El-Gallad \& Bremner, 1981).

Unfortunately, little is known of the mechanisms whereby $\mathrm{Fe}$ disturbs $\mathrm{Cu}$ metabolism and it is not clear whether the effect of $\mathrm{Fe}$ is on the absorption or the hepatic retention of $\mathrm{Cu}$. It does not depend on any reduction in food intake and there is some evidence of differences between species in response to variations in $\mathrm{Fe}$ supply. Thus, liver $\mathrm{Cu}$ concentrations in guinea pigs were reduced by $65 \%$ when their daily Fe intake was increased ten-fold to over $8 \mathrm{mg} / \mathrm{d}$ (Smith \& Bidlack, 1980) whereas liver $\mathrm{Cu}$ accumulation by pigs was unaffected by $\mathrm{Fe}$ unless they were given diets with $250 \mathrm{mg} \mathrm{Cu} / \mathrm{kg}$ (Hedges \& Kornegay, 1973). At lower $\mathrm{Cu}$ intakes, the response of the pigs was similar to that found in rats, where ${ }^{64} \mathrm{Cu}$ absorption and tissue $\mathrm{Cu}$ concentrations were unchanged or decreased only slightly by a dietary supplement of $1000 \mathrm{mg} \mathrm{Fe} / \mathrm{kg}$ diet (Bremner \& Young, 1981). However, supplementary Fe did greatly reduce ${ }^{64} \mathrm{Cu}$ absorption and tissue $\mathrm{Cu}$ levels in rats when their diet was also supplemented with sulphide, the magnitude of the effect then being much closer to that observed in the calves in this experiment (Bremner, Young et al. 1982).

Since dietary supplementation of rats with both $\mathrm{Mo}$ and $\mathrm{S}^{2-}$ also mimics certain of the effects of Mo in ruminants (Mills, El-Gallad \& Bremner, 1981) it is tempting to suggest that the inhibitory effect of $\mathrm{Fe}$ on $\mathrm{Cu}$ utilization in calves is, like Mo, dependent on interaction with $\mathrm{S}^{2-}$ in the rumen, with resultant decreases in $\mathrm{Cu}$ absorption. Some support for this view is provided by the observations that liver $\mathrm{Cu}$ concentrations in preruminant calves are not affected by the inclusion of $\mathrm{Fe}(500 \mathrm{mg} / \mathrm{kg}$ DM) in their milk-substitute ration and that the biliary excretion of $\mathrm{Cu}$ by weaned calves is unaffected by dietary $\mathrm{Fe}$ supplementation (I. Bremner, M. Phillippo, W. R. Humphries \& D. S. Graca, unpublished 
results). Experiments are in progress to determine whether the effect of $\mathrm{Fe}$ on $\mathrm{Cu}$ metabolism in calves is indeed influenced by variations in dietary S supply.

The existence of a common step in the $\mathrm{Mo}-\mathrm{Cu}$ and $\mathrm{Fe}-\mathrm{Cu}$ interactions in calves could perhaps explain why there was a highly significant interaction between $\mathrm{Fe}$ and $\mathrm{Mo}$ in the present experiment and why there were no major or consistent additive effects of the two antagonists on $\mathrm{Cu}$ metabolism in the calves in group FeMo. However, it cannot be excluded that each antagonist alone was having the maximum possible effect on the absorption of $\mathrm{Cu}$ and on the liberation of hepatic reserves of $\mathrm{Cu}$, so that there was no scope for further change. It will be necessary to determine the antagonistic effect of lower levels of both antagonists before this can be resolved. The findings will be of considerable importance to those concerned with the estimation of the requirements of ruminants for $\mathrm{Cu}$ and with the quantitation of the effects of specific dietary components on the utilization of $\mathrm{Cu}$.

The authors acknowledge the interest, which Dr C. F. Mills has shown in this research and thank Messrs I. McDonald, W. Lawson and J. Mathieson for assistance with statistical, haematological and Mo analyses. Dr Bain, Macaulay Institute for Soil Research, kindly carried out the $\mathrm{S}$ analyses on the diets.

\section{REFERENCES}

Agricultural Research Council (1976). The Nutrient Requirements of Livestock, no. 4, Composition of British Feedingstuffs. London: Agricultural Research Council.

Beauchamp, C. \& Fridovich, I. (1971). Analyt. Biochem. 44, 276.

Bingley, J. B. (1959). J. agric. Fd Chem. 7, 269.

Bremner, 1. \& Davies, N. T. (1980). In Digestive Physiology and Metabolism in Ruminants, p. 409 [Y. Ruckebusch \& P. Thivend, editors]. Lancaster: MTP Press Ltd.

Bremner, I., Mills, C. F. \& Young, B. W. (1982). J. inorg. Biochem. 16, 109.

Bremner, I. \& Young, B. W. (1978). Br. J. Nutr. 39, 325.

Bremner, I. \& Young, B. W. (1981). Proc. Nutr. Soc. 40, 69A.

Bremner, I., Young, B. W. \& Mills, C. F. (1982). Proc. Nutr. Soc. 41, 82A.

Campbell, A. G., Coup, M. R., Bishop, W. H. \& Wright, D. E. (1974). N.Z. Jl agric. Res. 17, 393.

Coup, M. R. \& Campbell, A. G. (1964). N.Z. Jl agric. Res. 7, 624.

Grun, M., Anke, M., Hennig, A., Seffner, W., Partschefeld, M., Flachowsky, G. \& Groppel, B. (1978). Archiv für Tierernährung $\mathbf{2 8}, 341$.

Healy, W. B. (1972). N.Z. Jl agric. Res. 15, 289.

Hedges, J. D. \& Kornegay, E. T. (1973). J. Anim. Sci. 37, 1147.

Humphries, W. R., Young, B. W., Phillippo, M. \& Bremner, I. (1981). Proc. Nutr. Soc. 40, 68A.

Kennedy, R. P. (1927). J. biol. Chem. 74, 385.

McMurray, C. H. (1980). In Biological Roles of Copper, Ciba Fdn Symp. no. 79, p. 183 [D. Evered and G. Lawrenson, editors]. Amsterdam: Excerpta Medica.

Mason, J., Lamand, M., Tressol, J. C. \& Lab, C. (1978). Ann. Rech. Vet. 9, 577.

Mills, C. F. (1980). In Biological Roles of Copper, Ciba Fdn Symp. no. 79, p. 49 [D. Evered and G. Lawrenson, editors]. Amsterdam: Excerpta Medica.

Mills, C. F., Dalgarno, A. C., Bremner, I. \& El-Gallad, T. T. (1977). Proc. Nutr. Soc. 36, 105 A.

Mills, C. F., Dalgarno, A. C. \& Wenham, G. (1976), Br. J. Nutr. 35, 309.

Mills, C. F., El-Gallad, T. T. \& Bremner, I. (1981). J. inorg. Biochem. 14, 189.

Mills, C. F., El-Gallad, T. T., Bremner, I. \& Wenham, G. (1981). J. inorg. Biochem. 14, 163.

Phillippo, M., Humphries, W. R., Bremner, I. \& Young, B. W. (1982). Proc. Nutr. Soc. 41, 80A

Quin, B. F. \& Woods, P. H. (1979). Analyst, Lond. 104, 552.

Roberts, H. E. (1976). Vet. Rec. 99, 496.

Ruutu, R. (1975). Clinica chim. Acta 61, 229.

Smith, B. P., Fisher, G. L., Poulos, P. W. \& Irwin, M. R. (1975). J. Am. vet. med. Ass. 166, 682.

Smith, B. S. W. \& Wright, H. (1974). Clin. Chim. Acta, 50, 359.

Smith, C. H. \& Bidlack, W. R. (1980). J. Nutr. 110, 1398.

Standish, J. F., Ammerman, C. B., Palmer, A. Z. \& Simpson, C. F. (1971). J. Anim. Sci. 33, 171.

Standish, J. F., Ammerman, C. B., Simpson, C. F., Neal, F. C. \& Palmer, A. Z. (1969). J. Anim. Sci. $29,496$.

Suttle, N. F. (1975). Br. J. Nutr. 34, 411.

Suttle, N. F., Alloways, B. J. \& Thornton, I. (1975). J. agr. Sci., Camb. 84, 249. 